Vol. 18 (2009): 302-316.

\title{
Role of benchmark technology in sustainable value analysis An application to Finnish dairy farms
}

\author{
Timo Kuosmanen ${ }^{1,2}$ and Natalia Kuosmanen ${ }^{1}$ \\ ${ }^{1}$ Economic Research Unit, MTT Agrifood Research Finland, Luutnantintie 13, FI-00410 Helsinki, Finland \\ ${ }^{2}$ Department of Business Technology, Helsinki School of Economics, PO Box 1210, FI-00101 Helsinki, Finland, \\ e-mail: firstname.lastname@mtt.fi
}

\begin{abstract}
Sustainability is a multidimensional concept that entails economic, environmental, and social aspects. The sustainable value (SV) method is one of the most promising attempts to quantify sustainability performance of firms. SV compares performance of a firm to a benchmark, which must be estimated in one way or another. This paper examines alternative parametric and nonparametric methods for estimating the benchmark technology from empirical data. Reviewed methods are applied to an empirical data of 332 Finnish dairy farms. The application reveals four interesting conclusions. First, the greater flexibility of the nonparametric methods is evident from the better empirical fit. Second, negative skewness of the regression residuals of both parametric OLS and nonparametric CNLS speaks against the average-practice benchmark technology in this application. Third, high positive correlations across a wide spectrum of methods suggest that the findings are relatively robust. Forth, the stochastic decomposition of the disturbance term to filter out the noise component from the inefficiency term yields more realistic efficiency estimates and performance targets.
\end{abstract}

Key-words: benchmarking, eco-efficiency, environmental performance, productive efficiency analysis, stochastic frontier estimation, sustainable value analysis, sustainable development. 


\section{AGRICULTURAL AND FOOD SCIENCE}

Vol. 18(2009): 302-316.

\section{Introduction}

Measuring corporate contributions to sustainability has attracted increasing attention in the recent years. A number of different practical approaches have been suggested (see e.g. Tyteca 1998). One of the most promising developments is sustainable value (SV), introduced by Figge and Hahn (2004, 2005). $\mathrm{SV}$ is a systematic economic approach for measuring sustainable value creation of firms. ${ }^{1} \mathrm{~A}$ firm is said to create sustainable value whenever it uses its bundle of resources more efficiently than another firm would have used it. In principle, reallocating resources from firms that create negative sustainable value to firms that create positive sustainable value can increase the economic welfare while keeping all stocks of capital in the economy at a constant level. Thus, firms creating sustainable value would be able to compensate for any rebound effects that might occur.

The recent study by Kuosmanen and Kuosmanen (2009) criticizes the original Figge and Hahn's SV estimator for making strong, unrealistic assumptions about a linear benchmark technology that is identified by just a single data point. Building an explicit link between SV method and the frontier approach to environmental performance assessment, ${ }^{2}$ Kuosmanen and Kuosmanen propose to use a more general benchmark technology, which can be estimated from empirical data using established econometric methods such as stochastic frontier analysis (SFA) or data envelopment analysis (DEA) (see e.g. Fried et al. 2007 for an up-to-date review of these methods).

The purpose of this paper is to provide a detailed examination and classification of alternative methods available for estimating the benchmark

1 By "firm" we refer to any productive unit, which may be a private or public organization, or an aggregated entity such as an industry, sector or country.

2 The frontier approach to environmental performance has a large and growing literature: see e.g. Färe et al. (1996), Tyteca $(1996,1997,1998)$, Callens and Tyteca (1999), Zaim (2004), Kuosmanen and Kortelainen (2005, 2007a), Cherchye and Kuosmanen (2006) and Kortelainen and Kuosmanen (2007), and references therein. technology in the context of SV analysis. On one hand, methods can be classified according to whether an average-practice or best-practice technology is estimated. The best-practice technologies can be further classified as deterministic and stochastic technologies, depending on whether a stochastic noise term is included or not. On the other hand, the methods can be classified as being parametric and nonparametric in their orientation. Parametric methods assume a specific functional form of the production function, which is usually linear in its parameters. Nonparametric methods do not assume a particular functional form, but estimate the benchmark technology based on some minimal set of axioms. In this paper we restrict to the standard monotonicity and concavity axioms; other possible sets of axioms fall beyond the scope of this paper. ${ }^{3}$

In addition to reviewing the theoretical properties and practical implementation of alternative methods, a critical examination of advantages and disadvantages of alternative methods is presented. To this end, we apply the alternative methods included in the review to data from a sample of 332 Finnish dairy farms. The data are obtained from the Farm Accountancy Data Network (FADN) database, and they can be seen as a typical data set used in the SV assessments in agricultural sector. The results of the empirical analysis reveal the critical role of parametric functional form assumptions on one hand, and the importance of accounting for stochastic noise on the other.

It should be noted that this study is one of the first empirical applications of the recently developed stochastic nonparametric envelopment of data (StoNED: Kuosmanen 2006, Kuosmanen and Kortelainen 2007b) and corrected convex nonparametric least squares (C ${ }^{2} \mathrm{NLS}$ : Kuosmanen and Johnson 2009) methods, respectively. These two methods are based on nonparametric least squares estimation subject to shape constraints (monotonicity, concavity) on the benchmark technology.

3 There are also other nonparametric methods such as the kernel estimation, which are based on local averaging (e.g. Fan et al. 1996). Such non-axiomatic methods fall beyond the scope of this paper. 
Kuosmanen, T. \& Kuosmanen, N. Benchmark technology in sustainable value analysis

The purpose of these methods is to bridge the gap between the existing parametric and nonparametric methods by combining the appealing characteristics of both approaches. Therefore, comparing the results of different estimation techniques in a relatively large sample of farms is also of methodological interest, providing insights and guidance for further methodological development.

\section{Sustainable Value}

Consider a production process where $R$ resources (including natural, physical, human, and intellectual capital) are transformed into economic output (e.g. gross or net value added, or some physical output). The resource use by firm $i$ is characterized by vector $\mathbf{x}_{i}=\left(x_{i 1} \ldots x_{i R}\right)^{\prime}$, and the economic output of firm $i$ is denoted by $y_{i}$. According to Figge and Hahn (2004, 2005), firm $i$ creates sustainable value if the economic output exceeds the opportunity cost of resource use. Thus, the SV measure is defined as the difference of output $y_{i}$ and the opportunity $\operatorname{cost}$ of $\mathbf{x}_{i}$. It is worth emphasizing that this relative measure does not tell if a particular firm is sustainable or not. It measures sustainability performance in a relative sense: by reallocating resources from firms with negative SV to those with positive value, a higher economic welfare could be achieved without increasing the total resource use of the economy.

To calculate SV, we need to know the opportunity cost of resources. Kuosmanen and Kuosmanen (2009) argue that the opportunity cost is not directly observable, but must be estimated from data in one way or another. In economics, the opportunity cost of using a resource for a specific activity refers to the income foregone by not using the resource in the best alternative activity. However, the best alternative use is not always self-evident. Kuosmanen and Kuosmanen argue that the best alternative use of a resource depends on both the available technology and the other resources available for the alternative activity.

To develop a rigorous definition of SV, Kuosmanen and Kuosmanen (2009) characterize the benchmark technology as production function $f: \mathbb{R}_{+}^{R} \rightarrow \mathbb{R}_{+}$, which indicates the maximum amount of output that the benchmark technology can produce using the given amounts of input resources. They interpret the numerical value of the production function $f(\mathbf{x})$ as the total opportunity cost of resource bundle $\mathbf{x}$, and the partial derivative $\partial f(\mathbf{x}) / \partial \mathbf{x}_{r}$ as the marginal opportunity cost of resource $r$ in point $\mathbf{x}$. In general, the marginal opportunity cost need not be constant but depends on the amount of other resources available.

The production function development of Kuosmanen and Kuosmanen (2009) implies the following general definition of SV:

$$
S V_{i}=y_{i}-f\left(\mathbf{x}_{i}\right)
$$

The rationale behind identity (1) comes from the conceptual definition by Figge and Hahn, but Kuosmanen and Kuosmanen's definition is more general because it does not assume linearity or any other particular functional form of $f$. More specifically, Figge and Hahn's (2004) original measure of SV is a special case of (1), obtained by specifying $f$ as a linear function $f(\mathbf{x})=\sum_{r=1}^{R} \beta_{r} x_{r}$ where coefficients $\beta_{r}=y^{*} / x_{r}{ }^{*}$ represent eco-efficiency of a pre-defined benchmark unit $\left(y^{*}, \boldsymbol{x}^{*}\right)$ in terms of resource $r$.

Interestingly, identity (1) defines SV as a residual between the observed output and the production function. Simply reorganizing identity (1) and introducing a random disturbance $v_{i}$, we obtain the regression equation

$$
y_{i}=f\left(\boldsymbol{x}_{i}\right)+\varepsilon_{i},=f\left(\boldsymbol{x}_{i}\right)+S V_{i}+v_{i},
$$

where $\varepsilon_{i}$ represents a composite disturbance term that consists of differences in sustainability performance across firms (i.e., sustainable value $S V_{i}$ ), and (optionally) the effects of measurement errors, differences in unobserved or omitted variables, and other deviations from the production function $f$, captured by the random noise term $v_{i}$. From this perspective, the generalized SV formulation (1) conforms with the classic approach to measuring performance differences across firms based on regression residuals (e.g. Timmer 1971, Richmond 1974). 


\section{Estimating benchmark technology}

\section{Classification}

We next review alternative methods available for estimating the benchmark technology. Taking equation (2) as a starting point, we will classify the methods in six categories according to how the production function $f$ and the composite disturbance $\varepsilon_{i}$ are specified.

Firstly, methods can be classified as parametric or nonparametric depending on the specification of the production function $f$. Parametric methods postulate a priori some specific functional form for $f$ (e.g. Cobb-Douglas, translog, or others) and subsequently estimate its unknown parameters. By contrast, nonparametric methods do not restrict to any single functional form, but assume only that $f$ satisfies certain regularity axioms (e.g. monotonicity and concavity).

Secondly, methods can be classified according to the interpretation of the composite disturbance $\varepsilon_{i}$ and the sustainable value $\mathrm{SV}_{i}$ as average-practice or best-practice approaches. In the average-practice approaches, $\varepsilon_{i}$ may be positive or negative, and no attempt is made to isolate the differences in sustainability performance $\mathrm{SV}_{i}$ from the noise term $v_{i}$. As a result, the estimated technology $f$ represents the average practice in the sample. The best-practice approaches generally estimate the frontier (i.e., the maximum output that can be produced with the given resources). The best-practice approaches can be further classified into deterministic and stochastic methods. The deterministic best-practice approaches assume away the noise term $v_{i}=0 \forall i=1, \ldots, n$, and assign all deviations from benchmark to one-sided inefficiency, implying $S V \leq 0 \quad \forall i=1, \ldots, n$. In stochastic best-practice approaches we interpret $\varepsilon_{i}$ as composite error term, from which the subcomponents of inefficiency and noise $\left(v_{i} \neq 0, S V_{i} \leq 0\right)$ can be estimated and isolated.

Combining the above described criteria gives us six different categories, as described in Table 1 together with some canonical references. In the following sub-sections, each of these six types of methods is described in more detail. We start from the parametric ordinary least squares (OLS), and its best-practice variants parametric programming (PP), corrected ordinary least squares (COLS), and the stochastic frontier analysis (SFA). We then proceed to the nonparametric approaches: convex

Table 1. Classification of methods

\begin{tabular}{llc}
\hline & parametric & $\begin{array}{l}\text { non-parametric } \\
\text { (f increasing and concave) }\end{array}$ \\
\hline average-practice & OLS & CNLS \\
& Cobb and Douglas (1928) & Hildreth (1954) \\
& & Hanson and Pledger (1976) \\
best-practice, & PP & DEA \\
deterministic & Aigner and Chu (1968) & Farrell (1957) \\
& Timmer (1971) & Charnes, Cooper, Rhodes (1978) \\
COLS & C2NLS \\
Winsten (1957) & Kuosmanen and Johnson (2009) \\
Gest-practice, & Greene (1980) & StoNED \\
stochastic & SFA & Kuosmanen (2006) \\
& Aigner, Lovell, and Schmidt (1977) & Kuosmanen and Kortelainen (2007b) \\
\hline
\end{tabular}

Abbreviations: OLS $=$ ordinary least squares, $\mathrm{PP}=$ parametric programming, $\mathrm{COLS}=$ corrected ordinary least squares, $\mathrm{SFA}=$ stochastic frontier analysis, CNLS = convex nonparametric least squares, DEA = data envelopment analysis, C2NLS = corrected convex nonparametric least squares, StoNED = stochastic nonparametric envelopment of data. 


\section{Kuosmanen, T. \& Kuosmanen, N. Benchmark technology in sustainable value analysis}

nonparametric least squares (CNLS), data envelopment analysis (DEA), corrected convex nonparametric least squares ( $\left.{ }^{2} \mathrm{NLS}\right)$, and stochastic nonparametric envelopment of data (StoNED).

\section{Ordinary Least Squares (OLS)}

OLS is the most standard and traditional estimation technique in econometrics and statistics (e.g. Greene 2007). OLS can be a useful method for estimating average practice benchmarks when one is only interested in the composite $\varepsilon_{i}$ term, and the distinction between the pure sustainable value $\left(S V_{i}\right)$ and the stochastic noise $\left(v_{i}\right)$ can be ignored. However, consistency of OLS requires that the composite $\varepsilon_{i}$ has a symmetric distribution. More specifically, estimation of SV by OLS requires the following Gauss-Markov assumptions: 1) $\varepsilon_{i}$ are andom variables that are uncorrelated with the resource use $\mathbf{x}_{i}$ and across observations, 2) the conditional distribution of $\varepsilon_{i}$ has zero mean (i.e. $\left.E\left(\varepsilon_{i} \mid \mathbf{x}_{i}\right)=0\right)$, and 3) the production function $f\left(\mathbf{x}_{i}\right)$ is linear (as implicitly assumed by Figge and Hahn). By assumption 3), equation (2) can be expressed in the matrix form as

$y_{i}=\alpha+\boldsymbol{\beta}^{\prime} \mathbf{x}_{i}+\varepsilon_{i}$.

Minimizing the sum of squares of $\mathrm{SV}_{i}$ statistics, we obtain the closed form solution $\hat{\varepsilon}_{i}=y_{i}-\left(\mathbf{X}^{\prime} \mathbf{X}\right)^{-1} \mathbf{X}^{\prime} \mathbf{y} \mathbf{x}_{i}^{\prime}$

where matrix $\mathbf{X}=\left(1 \mathbf{x}_{i} \ldots \mathbf{x}_{n}\right)$ and vector $y=\left(1 y_{i} \ldots y_{n}\right)^{\prime}$. Under assumptions 1)-3), the OLS estimator is unbiased, consistent, and has the smaller variance than any other linear estimator (i.e., OLS is the best linear unbiased estimator (BLUE)) (Greene 2007). Moreover, if we further assume that $\varepsilon_{i}$ are normally distributed, then OLS is the maximum likelihood estimator, and the conventional methods of statistical inference apply.

Let us take a closer look at the OLS assumptions. Firstly, assumption 3) of linear functional form can be easily relaxed; OLS can be applied as long as $f$ is a linear function of the unknown parameters $\alpha, \boldsymbol{\beta}$, which does not mean that $f$ is necessarily a linear function of resources $\mathbf{x}_{i}$. For example, the log-linear Cobb-Douglas function is nonlinear in $\mathbf{x}_{i}$ but linear in parameters $\alpha, \boldsymbol{\beta}$. Still, the functional form of $f$ must be assumed a priori, which introduces a risk of specification error.

Secondly, assumption 2) implies that the benchmark technology represents the average practice: $\varepsilon_{i}$ can be positive or negative, with the expected value zero. Importantly, if the composite disturbance $\varepsilon_{i}$ contains an asymmetric inefficiency component $S V_{i} \leq 0$, as commonly assumed in the frontier approach, the assumption 2) will be violated. If that is the case, the OLS estimator will be inconsistent and biased (see Kuosmanen and Fosgerau 2009). Introducing an asymmetric inefficiency term $S V_{i} \leq 0$ leads us to the best-practice methods, PP, COLS, and SFA, to be considered next.

Thirdly, violations of assumption 1) have been extensively studied in econometrics and there are methods for dealing with problems of endogeneity and serial correlation (see e.g. Greene 2007). For brevity, we here abstract from violations of assumption 1).

\section{Parametric programming (PP)}

Aigner and Chu (1968) were the first to estimate a best-practice frontier with the parametric regression techniques. Their parametric programming (PP) model can be seen as a deterministic frontier variant of the regression model (3), obtained by setting $v_{i}=0$, and $S V_{i} \leq 0 \forall i=1, \ldots, n$. The PP problem is

$\min _{\alpha, \beta, S V}\left\{\sum_{i=1}^{\mathrm{n}} S V_{i}^{2} \mid S V_{i} \leq 0 \forall i=1, \ldots, n ; y_{i}=\alpha+\boldsymbol{\beta}^{\prime} \mathbf{x}_{i}+S V_{i} \forall i=1, \ldots, n\right\}$

An alternative specification is to minimize the sum $\left(-\sum_{i=1}^{n} S V_{i}\right)$, leading to a linear programming problem. Whichever specification is used, the constrained programming problem (4) does not merely shift the OLS regression line upwards to the frontier, it also influences the coefficients: the estimated intercept and slope coefficients obtained by PP model (4) generally differ from the OLS estimates of (3).

\section{Corrected Ordinary Least Squares (COLS)}

Another deterministic best-practice approach (often confused with PP) is corrected ordinary least squares (COLS). The basic idea of COLS was first suggested 
Vol. 18(2009): 302-316.

by Winsten (1957); consistency of COLS estimator was formally shown by Greene (1980).

COLS is a two-stage procedure: in the first stage, the frontier is estimated by ordinary least squares (OLS) regression; and in the second stage, the frontier is shifted upwards such that the resulting COLS frontier envelopes all data. Note that the OLS residuals $\left(\hat{\varepsilon}_{i}^{O L S}\right)$ take both positive and negative values. In the COLS model, these error terms are attributed to inefficiency, thus the COLS estimator of SV is obtained as

$$
S V_{i}^{C O L S}=\hat{\varepsilon}_{i}^{O L S}-\max _{h} \widehat{\varepsilon}_{h}^{O L S}
$$

Values of $S V_{i}^{C O L S}$ range from $[0,-\infty]$, with 0 indicating efficient performance. Similarly, we adjust the intercept terms as

$\alpha^{C O L S}=\alpha^{O L S} \max _{h} \widehat{\varepsilon}_{h}^{O L S}$.

Slope coefficients $\widehat{\boldsymbol{\beta}}^{\text {COLS }}$ are obtained directly from (3) as $\hat{\boldsymbol{\beta}}^{C O L S}=\boldsymbol{\beta}^{O L S}$.

\section{Stochastic frontier analysis (SFA)}

SFA model developed by Aigner et al. (1977) and Meeusen and van den Broeck (1977) is nowadays the most frequently used parametric regression technique for estimating best-practice technologies. SFA differs from the deterministic approaches PP and COLS in that it includes a stochastic noise term $v_{i}$ that captures the effects of measurement errors, outliers, and other stochastic disturbances in the data. Filtering out the effects of stochastic noise $v_{i}$ from SV is an attractive feature of SFA.

The estimation of the SFA model requires certain distributional assumptions: the typical approach is to assume that the noise term is normally distributed with zero mean and unknown finite variance [i.e., $\left.v_{i} \sim N\left(0, \sigma_{v}^{2}\right)\right]$, and the pure sustainable value is half-normally distributed with an unknown variance [i.e., $\left.S V_{i} \sim N\left(0, \sigma_{S V}^{2}\right) \mid\right] .{ }^{4}$ In practice, the SFA

$4 \quad$ Alternative distributional assumptions about the inefficiency term are sometimes used (e.g. truncated normal, exponential, or gamma). However, the distribution does not influence the relative performance ranking of the firms. frontiers are usually estimated by maximum likelihood techniques. The maximum likelihood problem can be stated as

$$
\max _{\alpha, \beta, \sigma, \lambda}-n \ln \sigma+\sum_{i=1}^{n}\left[\ln \Phi\left(\frac{-\varepsilon_{i} \lambda}{\sigma}\right)-\frac{1}{2}\left(\frac{\varepsilon_{i}}{\sigma}\right)\right],
$$

where $\varepsilon_{i}=\alpha+\boldsymbol{\beta}^{\prime} \mathbf{x}_{i}-y_{i}, \lambda=\sigma_{S V} / \sigma_{v}, \sigma^{2}=\sigma_{S V}{ }^{2} / \sigma_{v}{ }^{2}$ and $\Phi$ is the cumulative distribution function of the standard normal distribution. The sustainable values must be inferred indirectly, using the conditional distribution at a given $\varepsilon_{i}$. Given the estimated ${ }^{\wedge} \sigma_{S V}, \hat{} \sigma_{v}$ from (7), Jondrow et al. (1982) have shown that the conditional expected value of the sustainable value of firm $i$ is obtained as

$E\left(S V \mid \hat{\varepsilon}_{i}\right)=-\frac{\hat{\varepsilon}_{i} \hat{\sigma}_{u}^{2}}{\hat{\sigma}_{u}^{2}+\hat{\sigma}_{v}^{2}}+\frac{\hat{\sigma}_{u}^{2} \hat{\sigma}_{v}^{2}}{\hat{\sigma}_{u}^{2} \hat{\sigma}_{v}^{2}}\left[\frac{\Phi\left(\hat{\varepsilon}_{i} / \hat{\sigma}_{v}^{2}\right)}{1-\Phi\left(\hat{\varepsilon}_{i} / \hat{\sigma}_{v}^{2}\right)}\right]$

where $\Phi$ is the density function of the standard normal distribution. The conditional expected value (8) is an unbiased but inconsistent estimator of $S V_{i}$ : irrespective of the sample size $n$, the variance of the estimator does not converge to zero.

While filtering the noise out is a convenient feature, SFA still requires the prior assumption about the functional form of $f$ (similar to OLS, PP, and COLS). However, we often have no good reason to prefer one functional form to another. Unfortunately, imposing a wrong functional form can be a source of specification errors that result as biased and inconsistent estimates. Sometimes, different functional forms have almost equally good empirical fit, but the ranking of firms according to sustainable value are dramatically different. Dependence on the prior imposed functional form is the main disadvantage of SFA compared to the nonparametric approaches to be discussed next.

\section{Concave Nonparametric Least Squares (CNLS)}

If the functional form of the regression function is not known beforehand, we can resort to nonparametric regression techniques. CNLS is the oldest approach in that literature, dating back to the work by Hildreth (1954). CNLS requires the same Gauss-Markov assumptions on the disturbance term $\varepsilon_{i}$ as imposed in OLS. In contrast to OLS, however, CNLS does not assume linearity or any other parametric functional 


\section{Kuosmanen, T. \& Kuosmanen, N. Benchmark technology in sustainable value analysis}

form for $f$. Rather, it postulates that $f$ belongs to the set of continuous, monotonic increasing and globally concave functions, denoted henceforth by $F_{2}$.

The CNLS problem finds $f \in F_{2}$ that minimizes the sum of squares of the deviations, formally: ${ }^{5}$

$\min _{f, \boldsymbol{\varepsilon}}\left\{\sum_{i=1}^{n} \varepsilon_{i}^{2} \mid y_{i}=f\left(\mathbf{x}_{i}\right)+\varepsilon_{i} \forall i=1, \ldots, n ; f \in F_{2}\right\}$

The CNLS problem (9) identifies the best-fit function $f$ from the family $F_{2}$, which includes an infinite number of possible functions. This makes problem (9) generally hard to solve. Existing single regressor algorithms (e.g. Meyer 1999) require that the data are sorted in ascending order according to the scalar valued regressor $x$. However, such a sorting is not possible in the general multiple regression setting where $\mathbf{x}$ is a vector.

To estimate the CNLS problem in the general multi-input setting, Kuosmanen (2008) has transformed the infinite dimensional problem (9) into an equivalent finite-dimensional quadratic programming (QP) problem that can be solved by standard mathematical programming algorithms:

$\min _{\boldsymbol{\alpha}, \boldsymbol{\beta}, \boldsymbol{\varepsilon}}\left\{\begin{array}{ll}\sum_{I=1}^{n} \varepsilon_{i}^{2} & \begin{array}{l}y_{i}=\alpha_{i}+\boldsymbol{\beta}_{i}^{\prime} \mathbf{x}_{i}+\varepsilon_{i} \forall i=1, \ldots, n ; \\ \alpha_{i}+\boldsymbol{\beta}_{i}^{\prime} \mathbf{x}_{i} \leq \alpha_{h}+\boldsymbol{\beta}_{h}^{\prime} \mathbf{x}_{i} \forall h, i=1, \ldots, n ; \\ \boldsymbol{\beta}_{i} \geq \mathbf{0} \forall i=1, \ldots, n\end{array}\end{array}\right\}$

Note that in contrast to models (3) and (4), in problem (10) the intercept and slope coefficients $\alpha_{i}, \boldsymbol{\beta}_{i}$ can differ from one firm to another. Instead of fitting one regression line to the cloud of observed points as in OLS, we fit $n$ different regression lines that can be interpreted as tangent lines to the unknown production function $f$. In this respect, Kuosmanen's QP representation (10) applies insights from the celebrated Afriat's Theorem (Afriat 1967, 1972). The slope coefficients $\boldsymbol{\beta}_{i}$ represent the marginal products of inputs (i.e., the sub-gradients $\left.\nabla f\left(\mathbf{x}_{i}\right)\right)$. The second constraint imposes concavity through a system of inequality constraints on tangent lines, known as the Afriat inequalities: these

5 For statistical properties of the CNLS estimators, see e.g. Groeneboom et al. (2001) and references therein. inequalities are the key to modeling concavity constraints in the general multiple regressor setting. The third constraint imposes monotonicity.

Given the estimated coefficients $\alpha_{i}, \boldsymbol{\beta}_{i}$ from (10), we can construct the following piece-wise estimator of the benchmark technology:

$$
f^{C N L S}(\mathbf{x})=\min _{i \in\{1, \ldots, n\}}\left\{\alpha_{i}+\boldsymbol{\beta}_{i}^{\prime} \mathbf{x}\right\}
$$

In principle, estimator $f^{C N L S}$ consists of $n$ hyperplane segments. In practice, however, the estimated coefficients $\alpha_{i}, \boldsymbol{\beta}_{i}$ are clustered to a relatively small number of alternative values: the number of different hyperplane segments is usually much lower than $n$ (see Kuosmanen 2008)

Analogous to OLS, CNLS estimates the average-practice benchmark. It hence shares the same problem as OLS: if the composite disturbance $\varepsilon_{i}$ contains an asymmetric component $S V_{i} \leq 0$, the exogeneity assumption $E\left(\varepsilon_{i} \mid \mathbf{x}_{i}\right)=0$ will be violated. If that is the case, the CNLS estimator will be inconsistent and biased. Introducing an asymmetric inefficiency term $S V_{i} \leq 0$ leads us to the bestpractice methods, DEA, C ${ }^{2}$ NLS, and StoNED, to be considered next.

\section{Data envelopment analysis (DEA)}

Data envelopment analysis (DEA) (Charnes et al. 1978) is the most widely used nonparametric frontier approach. DEA is a deterministic linear programming method. DEA does not require any prior assumptions about the functional form of function $f$, but only assumes that $f$ belongs to the family of monotonic increasing and globally concave functions $\left(F_{2}\right)$, similar to CNLS. An important advantage of DEA is that it does not require any statistical assumptions about the composite distubance term $\varepsilon_{i}$. However, assuming away noise (i.e., $v_{i}=0 \forall i=1, \ldots, n$ ) is a strong assumption as such.

DEA estimator of production function $f$ can be expressed as ${ }^{6}$

6 Formulation (12) was first presented by Afriat 


\section{AGRICULTURAL AND FOOD SCIENCE}

Vol. 18(2009): 302-316.

$f_{D E A}(\mathbf{x})=\max _{\lambda \geq 0}\left\{\sum_{i=1}^{n} \lambda_{i} y_{i} \mid \mathbf{x} \geq \sum_{i=1}^{n} \lambda_{i} \mathbf{x}_{i} ; \sum_{i=1}^{n} \lambda_{i}=1\right\}$.

This yields a continuous, piece-wise linear frontier that envelopes the observed data from above. If $y_{i}=f_{D E A}\left(\mathbf{x}_{i}\right)$, then $S V_{i}=0$, and the firm is diagnosed as efficient. If $y_{i}<f_{D E A}\left(\mathbf{x}_{i}\right)$, then $S V_{i}<0$, and the firm is said to be inefficient. In standard DEA, outcome $y_{i}>f_{D E A}\left(\mathbf{x}_{i}\right)$ is not possible. Given a resource vector $\mathbf{x}$, the values of this production function are easy to compute by linear programming.

DEA estimator (12) can be interpreted as a nonparametric counterpart to Aigner and Chu's (1968) PP method described above (see Kuosmanen and Jonson 2009). The main advantage of DEA is its more general and flexible specification of $f$. However, DEA assumes away the stochastic noise term $v$, similar to the PP and COLS methods reviewed above.

Corrected convex nonparametric least squares $\left(C^{2} N L S\right)$

Kuosmanen and Johnson (2009) have recently proposed to combine the classic idea of COLS estimation to the CNLS method described above, referring to the new method as $\mathrm{C}^{2} \mathrm{NLS}$. The practical implementation of $\mathrm{C}^{2} \mathrm{NLS}$ method consists of two steps. In step 1), we estimate the average-practice frontier using CNLS (equation (10). To estimate the deterministic best-practice frontier, we shift the frontier in step 2) directly analogous to the COLS procedure (equations (5) and (6)): the $\mathrm{C}^{2} \mathrm{NLS}$ estimator for SV can be formally stated as

$$
S V_{i}^{C 2 N L S}=\hat{\varepsilon}_{i}^{C N L S}-\max _{h} \hat{\varepsilon}_{h}^{C N L S} .
$$

If the sustainable values $S V_{i}$ are independently distributed across firms, $\mathrm{C}^{2} \mathrm{NLS}$ provides a more efficient estimator than DEA. However, DEA does not require any independence assumption, and it

(1972), who formally proved that (12) is the minimal function that envelops all observed data points and satisfies monotonicity and concavity. is more robust to heteroskedasticity. On the other hand, the regression interpretation of the $C^{2} \mathrm{NLS}$ method enables one to introduce contextual variables that explain differences in sustainability performance in the same regression model, thus avoiding the pitfalls of the two-stage semiparametric estimation (see Johnson and Kuosmanen 2009, for details). It also paves a way for introducing a stochastic noise term $v$ to the nonparametric frontier estimation.

Stochastic nonparametric envelopment of data (StoNED)

Stochastic Nonparametric Envelopment of Data (StoNED) is a new estimation method developed by Kuosmanen (2006) and Kuosmanen and Kortelainen (2007b). Like CNLS, DEA, and $\mathrm{C}^{2}$ NLS, StoNED does not require any prior functional form assumption about $f$, but only assumes that $f$ belongs to the family $F_{2}$. The StoNED method differs from DEA and $\mathrm{C}^{2} \mathrm{NLS}$ in that it decomposes the deviations of $y_{i}$ from $f\left(\mathbf{x}_{i}\right)$ into two sources: the pure sustainable value $S V_{i}$ and the stochastic noise term $v_{i}$, similar to SFA. In other words, StoNED combines the deterministic part of DEA with the stochastic part of SFA, thus combining the key advantages of both methods.

The practical estimation of the StoNED model is conducted in two stages. In the first stage, the conditional expected value of $y$ is estimated by CNLS regression (equation (10)). Given the CNLS residuals from problem (10), we subsequently filter out the noise from the sustainable values. This requires some distributional assumptions, e.g. the standard SFA assumptions $v_{i} \sim N\left(0, \sigma_{v}^{2}\right)$ and $S V_{i} \sim\left|N\left(0, \sigma_{S V}^{2}\right)\right|$. Parameters $\sigma_{S V}, \sigma_{v}$ can be estimated by the method of moments or maximum pseudolikelihood techniques (see Kuosmanen and Kortelainen 2007b for details). The conditional expectation of the sustainable value is then computed using the Jondrow et al. formula (8).

StoNED offers a general framework that encompasses both DEA and SFA as its special cases. Specifically, if we restrict the noise component $v_{i}$ equal to zero, StoNED falls back to the standard DEA. On the other hand, if we impose some particular functional form on $f$, then StoNED boils 
Kuosmanen, T. \& Kuosmanen, N. Benchmark technology in sustainable value analysis

down to SFA. The main advantage of StoNED to the parametric SFA is the independence of the ad hoc assumptions about the functional form of the benchmark technology. On the other hand, the main advantage of StoNED to the nonparametric DEA is the better robustness to outliers, data errors, and other stochastic noise in the data. While in DEA the benchmark technology is spanned by a relatively small number of efficient firms, in StoNED all observations influence the benchmark.

\section{Application to Finnish dairy farms}

\section{Objectives}

We next apply the eight estimation methods described and classified in the previous section to the empirical data of 332 Finnish dairy farms. Objectives of this exercise are three-fold. First, the application illustrates the results and information obtainable with alternative methods. Second, application of different methods enables us to compare the SV estimates, and analyze their correlations. Third, the results enable us to critically evaluate the advantages and disadvantages of alternative methods. Thus, this analysis sheds further light on the choice of the benchmark technology in SV analysis. Although the sustainability performance of dairy farms is of considerable interest per se (see, e.g. van Passel et al. 2007), our main focus is on the comparison of alternative estimation methods in a typical empirical data.

\section{Data}

The data set is obtained from the FADN database. The output and the resource use are measured on per hectare basis. The economic output is the total revenue from milk and other products, and is expressed in $€$ $\mathrm{ha}^{-1}$. Economic resources include labor $\left(\mathrm{hr} \mathrm{ha}^{-1}\right)$ and farm capital $\left(€ \mathrm{ha}^{-1}\right)$. Unfortunately, farm level data on environmental and social resources of dairy farms are extremely limited for the purposes of sustainability assessment. As two environmental resources extractable from the FADN data, we include the total energy $\operatorname{cost}\left(€ \mathrm{ha}^{-1}\right)$ and the net nitrogen use $\left(\mathrm{kg} \mathrm{N} \mathrm{ha}^{-1}\right)$. The net nitrogen use has been calculated based on farm gate nitrogen surplus method (Nevens et al. 2006, Virtainen and Nousiainen 2005). The limited scope of the sustainability indicators is an obvious shortcoming of this data set, but similar data problems arise in virtually all farm-level environmental efficiency or SV analyses (see e.g. Reinhard et al. 1999, van Passel et al. 2007, and references therein).

Descriptive statistics of the sample data are reported in Table 2 . The output varies from $561 €$ ha $^{-1}$ up till 6,691 $€ \mathrm{ha}^{-1}$, with a distribution skewed heavily to the left. The labor, capital, and energy intensities also exhibit large variance and skewness to left. Net nitrogen surplus is positive at all farms included in the sample, with the average value of $72 \mathrm{~kg} \mathrm{~N} \mathrm{ha}{ }^{-1}$.

We next applied the eight methods described in the previous section and classified in Table 1. For the parametric methods, the log-linear Cobb-Douglas functional form has been used. For DEA, the output-oriented variable returns to scale specification is used. For the stochastic SFA and StoNED

Table 2. Data set descriptive statistics for the year 2004, sample size equals 332 Finnish dairy farms

\begin{tabular}{lcccc}
\hline variable & mean & standard deviation & minimum & maximum \\
\hline Total output, $€ \mathrm{ha}^{-1}$ & 1,948 & 760 & 561 & 6,691 \\
Labor, hr ha & 124 & 61 & 25 & 421 \\
Farm capital, $€ \mathrm{ha}^{-1}$ & 5,282 & 2,573 & 1,172 & 20,493 \\
Energy, $€ \mathrm{ha}^{-1}$ & 125 & 56.5 & 42 & 433 \\
Net N surplus, $\mathrm{kg} \mathrm{ha}^{-1}$ & 72 & 25.5 & 5.4 & 210 \\
\hline
\end{tabular}




\section{AGRICULTURAL AND FOOD SCIENCE}

Vol. 18(2009): 302-316.

methods, we assume the half-normal SV distribution and normally distributed noise. The variance decomposition of SFA and StoNED has been conducted by the method of moments. In SFA, residuals of the log-linear OLS model were used. In StoNED, the residuals of the CNLS model were divided by the output per hectare to circumvent heteroskedasticity, and thus obtained standardized residuals were used in the variance decomposition.

\section{Results}

Table 3 reports the summary statistics of the SV estimates obtained with each method, together with the coefficient of determination $R^{2}=1-(S S E / S S T)$, where $S S E$ is the sum of squares of residuals and $S S T$ is the sum of squares of output $y$ around its mean. For comparability, we calculated the SSE for all methods using difference $y-f(\mathbf{x})$, attributing both the SV and noise components in the unexplained variance. Comparing the $R^{2}$ statistics of the parametric methods and their nonparametric counterparts, we observe that the latter group of methods yields somewhat better empirical fit in all specifications. This is an expected result, given the greater flexibility of the nonparametric specification.

Comparing the SV estimates of the averagepractice and best-practice methods, we note that the latter ones indicate a negative SV value for all farms: it is not possible to perform better than the best practice. The positive mean SV of OLS estimates is due to the log-transformation. The deterministic methods COLS and $\mathrm{C}^{2} \mathrm{NLS}$ indicate the smallest average and median SV statistic, suggesting highest degree of inefficiency. The stochastic methods SFA and StoNED have a smaller variance in SV statistics. This is because the stochastic methods filter out the noise component from the composite disturbance term.

It is also interesting to compare the correlations in SV estimates across farms. Table 4 reports the correlation table with the Pearson product moment correlation coefficients for the SV estimates and the Spearman rank correlation coefficients (in pa- rentheses). By construction, SV estimates obtained by OLS and COLS methods exhibit perfect correlation. The same is true for the nonparametric CNLS and $\mathrm{C}^{2} \mathrm{NLS}$ methods. In general, the SV estimates and rankings obtained from most methods are highly correlated. A notable exception is DEA, which yields SV estimates that are negatively correlated with all other method, except for a small positive correlation with StoNED. Except for DEA, other nonparametric SV estimates are highly correlated with each other, and the same is true for the parametric estimates. The CNLS and $\mathrm{C}^{2} \mathrm{NLS}$ estimates are relatively highly correlated with the parametric estimates, SFA and PP in particular. We may interpret the positive correlations across the spectrum of methods (except for DEA) as evidence for robustness in the SV estimates and rankings.

Differences in the SV performance at the farm level are lost in the summary statistics and correlation tables. However, reporting the SV statistics for all 332 farms is not practical. To shed some light on sustainability performance at the farm-level, Table 5 reports the SV estimates and relative ranks for the five farms with the lowest and the highest output per hectare in the sample, respectively, labeled as farms no. 1-5 and 328-332. The upper part of Table 5 reports the SV estimates (left column) and the relative rankings (right column) of these ten farms obtained by using the parametric methods (OLS, PP, COLS, and SFA). Analogously, the lower part of Table 5 reports the corresponding SV statistics and farm rankings obtained by using the nonparametric methods (CNLS, DEA, C ${ }^{2}$ NLS, and StoNED). Despite the high correlations in SV estimates and rankings across method at the level of the entire sample, the farm-level SV estimates and rankings exhibit substantial differences across methods. For example, farm no. 332 performs relatively well according to OLS and COLS (rank 10), whereas this farm is one of the worst performers according to StoNED (rank 326 out of 332). On the other hand, farm no. 3 is one of the best farms according to the StoNED model, but OLS and COLS rank it as 283. For an individual farm, different methods can show a dramatically different picture about the relative performance, let alone the absolute improvement potential. 
Kuosmanen, T. \& Kuosmanen, N. Benchmark technology in sustainable value analysis

Table 3. Descriptive statistics of sustainable value (SV) estimates and coefficients of determination $\left(R^{2}\right)$

\begin{tabular}{|c|c|c|c|}
\hline & & parametric & non-parametric \\
\hline \multirow[t]{7}{*}{ average-practice } & & OLS & CNLS \\
\hline & mean: & $45.36 € \mathrm{ha}^{-1}$ & $0.00 € \mathrm{ha}^{-1}$ \\
\hline & median: & $46.03 € \mathrm{ha}^{-1}$ & $40.23 € \mathrm{ha}^{-1}$ \\
\hline & st. dev.: & $430.44 € \mathrm{ha}^{-1}$ & $341.30 € \mathrm{ha}^{-1}$ \\
\hline & $\min :$ & $-1114.00 € \mathrm{ha}^{-1}$ & $-1581.72 € \mathrm{ha}^{-1}$ \\
\hline & $\max :$ & $1477.77 € \mathrm{ha}^{-1}$ & $1176.17 € \mathrm{ha}^{-1}$ \\
\hline & $R^{2}:$ & 0.679 & 0.798 \\
\hline \multirow{14}{*}{$\begin{array}{l}\text { best-practice, } \\
\text { deterministic }\end{array}$} & & PP & DEA \\
\hline & mean: & $-1057.68 € \mathrm{ha}^{-1}$ & $-776.82 € \mathrm{ha}^{-1}$ \\
\hline & median: & $-1028.38 € \mathrm{ha}^{-1}$ & $-773.92 € \mathrm{ha}^{-1}$ \\
\hline & st. dev.: & $491.24 € \mathrm{ha}^{-1}$ & $461.86 € \mathrm{ha}^{-1}$ \\
\hline & $\min :$ & $-3045.42 € \mathrm{ha}^{-1}$ & $-2163.73 € \mathrm{ha}^{-1}$ \\
\hline & $\max :$ & $0 € \mathrm{ha}^{-1}$ & $0 € \mathrm{ha}^{-1}$ \\
\hline & $R^{2}:$ & 0.582 & 0.631 \\
\hline & & COLS & $\mathrm{C}^{2} \mathrm{NLS}$ \\
\hline & mean: & $-1432.41 € \mathrm{ha}^{-1}$ & $-1176.17 € \mathrm{ha}^{-1}$ \\
\hline & median: & $-1431.73 € \mathrm{ha}^{-1}$ & $-1135.94 € \mathrm{ha}^{-1}$ \\
\hline & st. dev.: & $430.44 € \mathrm{ha}^{-1}$ & $341.30 € \mathrm{ha}^{-1}$ \\
\hline & min: & $-2591.76 € \mathrm{ha}^{-1}$ & $-2757.89 € \mathrm{ha}^{-1}$ \\
\hline & $\max :$ & $0 € \mathrm{ha}^{-1}$ & $0 € \mathrm{ha}^{-1}$ \\
\hline & $R^{2}$ & 0.679 & 0.798 \\
\hline \multirow{7}{*}{$\begin{array}{l}\text { best-practice, } \\
\text { stochastic }\end{array}$} & & SFA & StoNED \\
\hline & mean: & $-327.27 € \mathrm{ha}^{-1}$ & $-310.60 € \mathrm{ha}^{-1}$ \\
\hline & median: & $-292.07 € \mathrm{ha}^{-1}$ & $-256.35 € \mathrm{ha}^{-1}$ \\
\hline & st. dev.: & $267.47 € \mathrm{ha}^{-1}$ & $283.22 € \mathrm{ha}^{-1}$ \\
\hline & $\min :$ & $-1547.50 € \mathrm{ha}^{-1}$ & $-1741.11 € \mathrm{ha}^{-1}$ \\
\hline & $\max :$ & $0 € \mathrm{ha}^{-1}$ & $0 € \mathrm{ha}^{-1}$ \\
\hline & $R^{2}:$ & 0.679 & 0.798 \\
\hline
\end{tabular}

Abbreviations: OLS = ordinary least squares, $\mathrm{PP}=$ parametric programming, COLS $=$ corrected ordinary least squares, $\mathrm{SFA}=$ stochastic frontier analysis, CNLS = convex nonparametric least squares, DEA = data envelopment analysis, $\mathrm{C}^{2} \mathrm{NLS}=$ corrected convex nonparametric least squares, StoNED = stochastic nonparametric envelopment of data.

Table 4. Correlation matrix of SV estimates; Pearson product moment correlation coefficients (Spearman rank correlation coefficients in parentheses)

\begin{tabular}{|c|c|c|c|c|c|c|c|c|c|}
\hline & OLS & & PP & COLS & SFA & CNLS & DEA & C2NLS & StoNED \\
\hline OLS & & 1 & $\begin{array}{l}0.819 \\
(0.792)\end{array}$ & 1 & $\begin{array}{l}0.882 \\
(0.935)\end{array}$ & $\begin{array}{l}0.642 \\
(0.619)\end{array}$ & $\begin{array}{l}-0.053 \\
(-0.024)\end{array}$ & $\begin{array}{l}0.642 \\
(0.619)\end{array}$ & $\begin{array}{l}0.328 \\
(0.341)\end{array}$ \\
\hline PP & & & 1 & $\begin{array}{l}0.819 \\
(0.792)\end{array}$ & $\begin{array}{l}0.819 \\
(0.946)\end{array}$ & $\begin{array}{l}0.752 \\
(0.724)\end{array}$ & $\begin{array}{l}-0.035 \\
(-0.039)\end{array}$ & $\begin{array}{l}0.752 \\
(0.724)\end{array}$ & $\begin{array}{l}0.648 \\
(0.637)\end{array}$ \\
\hline COLS & & & & 1 & $\begin{array}{l}0.882 \\
(0.935)\end{array}$ & $\begin{array}{l}0.642 \\
(0.619)\end{array}$ & $\begin{array}{l}-0.053 \\
(-0.024)\end{array}$ & $\begin{array}{l}0.642 \\
(0.619)\end{array}$ & $\begin{array}{l}0.328 \\
(0.341)\end{array}$ \\
\hline SFA & & & & & 1 & $\begin{array}{l}0.778 \\
(0.748) \\
\end{array}$ & $\begin{array}{c}-0.022 \\
(-0.025) \\
\end{array}$ & $\begin{array}{l}0.778 \\
(0.748) \\
\end{array}$ & $\begin{array}{l}0.619 \\
(0.565) \\
\end{array}$ \\
\hline CNLS & & & & & & 1 & $\begin{array}{r}-0,008 \\
(0.007)\end{array}$ & 1 & $\begin{array}{l}0.902 \\
(0.914)\end{array}$ \\
\hline DEA & & & & & & & 1 & $\begin{array}{r}-0.008 \\
(0.007)\end{array}$ & $\begin{array}{l}0.013 \\
(0.018)\end{array}$ \\
\hline C2NLS & & & & & & & & 1 & $\begin{array}{l}0.902 \\
(0.914)\end{array}$ \\
\hline StoNED & & & & & & & & & 1 \\
\hline
\end{tabular}

Abbreviations: OLS $=$ ordinary least squares, $\mathrm{PP}=$ parametric programming, $\mathrm{COLS}=$ corrected ordinary least squares, $\mathrm{SFA}=$ stochastic frontier analysis, CNLS = convex nonparametric least squares, DEA = data envelopment analysis, C2NLS = corrected convex nonparametric least squares, StoNED = stochastic nonparametric envelopment of data. 
Vol. 18(2009): 302-316.

Table 5. Sustainable value (SV) statistics and relative rankings of the five least productive (no. 1-5) and most productive (no 328-332) farms in terms of output per hectare

\begin{tabular}{|c|c|c|c|c|c|c|c|c|c|}
\hline \multicolumn{2}{|c|}{ parametric methods } & \multicolumn{2}{|c|}{ OLS } & \multicolumn{2}{|c|}{ PP } & \multicolumn{2}{|c|}{ COLS } & \multicolumn{2}{|c|}{ SFA } \\
\hline farm no. & output $\left(€ \mathrm{ha}^{-1}\right)$ & SV & rank & SV & rank & SV & rank & SV & rank \\
\hline 1) & 561 & -557.3 & 311. & -1272.9 & 239. & -2035.1 & 311. & -560.9 & 281. \\
\hline 2) & 748 & -233.5 & 260. & -814.8 & 98. & -1711.3 & 260. & -336.3 & 187. \\
\hline 3) & 775 & -374.9 & 283. & -1185.4 & 209. & -1852.6 & 283. & -459.9 & 250. \\
\hline 4) & 788 & -210.1 & 253. & -875.7 & 123. & -1687.8 & 253. & -323.6 & 180. \\
\hline \multirow[t]{2}{*}{ 5) } & 817 & -35.0 & 194. & -541.9 & 44. & -1512.8 & 194. & -175.4 & 113. \\
\hline & $\ldots$ & & & & & & & & \\
\hline 328) & 4033 & 1220.0 & 6. & -382.9 & 24. & -257.8 & 6. & -8.8 & 24. \\
\hline 329) & 4727 & 1098.4 & 11. & -605.5 & 52. & -379.4 & 11. & -24.2 & 49. \\
\hline 330) & 4769 & 1477.8 & 1. & -295.1 & 16. & 0.0 & 1. & -9.3 & 29. \\
\hline 331) & 5052 & 1283.9 & 4. & -651.9 & 61. & -193.9 & 4. & -18.7 & 42. \\
\hline 332) & 6691 & 1127.9 & 10. & -1728.4 & 305. & -349.8 & 10. & -159.0 & 102. \\
\hline \multicolumn{2}{|c|}{ nonparametric methods } & \multicolumn{2}{|c|}{ CNLS } & \multicolumn{2}{|c|}{ DEA } & \multicolumn{2}{|c|}{$\mathrm{C}^{2} \mathrm{NLS}$} & \multicolumn{2}{|c|}{ StoNED } \\
\hline farm no. & output $\left(€\right.$ ha $\left.^{-1}\right)$ & SV & rank & SV & rank & SV & rank & SV & rank \\
\hline 1) & 561 & -107.1 & 220. & -425.1 & 78. & -1283.3 & 220. & -172.7 & 133. \\
\hline 2) & 748 & 124.0 & 129. & -1548.7 & 314. & -1052.2 & 129. & -14.8 & 36. \\
\hline 3) & 775 & 244.0 & 73. & -167.3 & 39. & -932.1 & 73. & 0.0 & 1. \\
\hline 4) & 788 & 190.1 & 91. & -825.2 & 179. & -986.1 & 91. & -1.9 & 10. \\
\hline 5) & 817 & 135.1 & 121. & -911.4 & 204. & -1041.1 & 121. & -16.4 & 40. \\
\hline & $\cdots$ & & & & & & & & \\
\hline 328) & 4033 & 600.5 & 9. & -538.1 & 100. & -575.7 & 9. & -131.5 & 110. \\
\hline 329) & 4727 & -536.6 & 314. & -716.7 & 151. & -1712.8 & 314. & -1158.5 & 327. \\
\hline 330) & 4769 & 456.4 & 21. & -1013.6 & 235. & -719.8 & 21. & -360.8 & 208. \\
\hline 331) & 5052 & 43.0 & 164. & -840.6 & 182. & -1133.2 & 164. & -738.9 & 308. \\
\hline 332) & 6691 & -145.3 & 233. & -615.5 & 119. & -1321.5 & 233. & -1142.5 & 326. \\
\hline
\end{tabular}

Abbreviations: OLS = ordinary least squares, $\mathrm{PP}=$ parametric programming, $\mathrm{COLS}=$ corrected ordinary least squares, $\mathrm{SFA}=$ stochastic frontier analysis, $\mathrm{CNLS}=$ convex nonparametric least squares, DEA $=$ data envelopment analysis, $\mathrm{C} 2 \mathrm{NLS}=\mathrm{corrected}$ convex nonparametric least squares, StoNED = stochastic nonparametric envelopment of data. 
Kuosmanen, T. \& Kuosmanen, N. Benchmark technology in sustainable value analysis

\section{Concluding discussion}

Starting from a generalized formulation of sustainable value that is consistent with nonlinear benchmark technologies and facilitates estimation of the benchmarks from empirical data, we have reviewed eight alternative methods for estimating benchmark technologies and sustainable value scores. We distinguished between parametric and nonparametric approaches, depending on the assumed functional form of the benchmark technology. We also draw distinction between average-practice and best-practice approaches, further classifying the best-practice approaches into deterministic and stochastic methods. For each six categories, there are sound estimation methods that can be applied in empirical SV analysis.

To shed further light on the choice of the estimation method, the eight approaches reviewed in this paper were applied to the empirical production data of 332 Finnish dairy farms. Based on the results of the application, the following conclusions can be drawn.

Firstly, the nonparametric methods achieved a better empirical fit than their parametric counterparts in terms of to the coefficient of determination $\left(R^{2}\right)$. This is one of the benefits from the greater flexibility of the nonparametric specification that does not force the benchmark technology to a rigid structure of some parametric functional form. The nonparametric approaches considered in this paper build upon the monotonicity and concavity axioms, which ensure that the estimated benchmark technology conforms with the regularity conditions of the microeconomic theory. However, possible violations of the regularity conditions can be detrimental for the nonparametric methods. Except for DEA, the nonparametric methods are also computationally demanding. For example, computing the CNLS problem (10) with GAMS software required more than 3.2 Million iterations. The benefits of nonparametric estimation do not come without cost.

Secondly, significant negative skewness in the regression residuals of both parametric OLS and nonparametric CNLS speak against using the average-practice benchmarks in this application. As we have noted, estimating an average practice benchmark technology in the presence of an asymmetric inefficiency component in the disturbance term yields biased and inconsistent estimates.

Thirdly, high positive correlations across a wide spectrum of methods (except for DEA) in both the SV estimates and the relative rankings suggest that the findings from the regression based approaches are relatively robust to possible specification errors, sampling errors, and data problems. The results from DEA analysis are likely perturbed by measurement errors, outliers, and other noise in data, to which DEA estimates are known to be sensitive.

Fourthly, the deterministic best-practice benchmarks indicate enormous improvement potential in sustainability performance, but it is questionable whether such performance targets are realistic. While we have used the best data available for a typical SV analysis at the farm level, the data are far from perfect. There are a number of omitted factors and sources of error that must be acknowledged. For these reasons, the stochastic frontier methods SFA and StoNED, which filter out the noise component from the inefficiency term and attribute only a part of the deviations from the frontier to the SV estimate, are likely to provide more realistic estimates of the sustainable improvement potential, which translates into more realistic performance targets at the farm level.

In conclusion, a number of methods for estimating benchmark technologies are available. The choice of the estimation method depends on the quality and coverage of data, the sample size, the number of resources, among other considerations. Since there is no single superior method for all applications, reporting estimates of several alternative methods can shed some light on the robustness of results.

Acknowledgements. This paper has benefited of comments and suggestions from two anonymous reviewers of this journal as well as participants to the SVAPPAS project (http://www.svappas.ugent.be). Financial support from the 6th Framework Programme of the EU for this project is gratefully acknowledged (project code: SSPE- 


\section{AGRICULTURAL AND FOOD SCIENCE}

Vol. 18(2009): 302-316.

CT-2006-44215). The usual disclaimer applies: the views expressed in this paper are those of the authors and not necessarily those of their organizations or sponsors, nor those who have commented on the earlier draft versions.

\section{References}

Afriat S.N. 1967. The construction of a utility function from expenditure data. International Economic Review 8: $67-77$.

Afriat S.N. 1972. Efficiency estimation of production functions. International Economic Review 13: 568-598.

Aigner D. \& Chu S. 1968. On estimating the industry production function. American Economic Review 58: $826-$ 839.

Aigner D., Lovell C.A.K. \& Schmidt P. 1977. Formulation and estimation of stochastic frontier production function models. Journal of Econometrics 6: 21-37.

Callens I. \& Tyteca D. 1999. Towards indicators of sustainable development for firms: a productive efficiency perspective. Ecological Economics 28: 41-53.

Charnes A. Cooper W.W. \& Rhodes E. 1978. Measuring the efficiency of decision making units. European Journal of Operational Research 2: 429-444.

Cherchye L. \& Kuosmanen T. 2006. Benchmarking sustainable development: A synthetic meta-index approach. Ch. 7 in McGillivray M. \& Clarke M. (eds): Understanding Human Well-being. United Nations University Press, Tokyo.

Cobb C.W. \& Douglas P.H. 1928. A Theory of production. American Economic Review 18: 139-165.

Fan Y., Li Q. \& Weersink A. 1996. Semiparametric estimation of stochastic production frontier models. Journal of Business and Economic Statistics 14: 460-468.

Färe R., Grosskopf S. \& Tyteca D. 1996. An activity analysis model of the environmental performance of firms: Application to fossil-fuel-fired electric utilities. Ecological Economics 18: 161-175.

Farrell M.J. 1957. The measurement of productive efficiency. Journal of the Royal Statistical Society, Series A 120: $253-281$.

Figge F. \& Hahn T. 2004. Sustainable value added - measuring corporate contributions to sustainability beyond eco-efficiency. Ecological Economics 48: 173-187.

Figge F. \& Hahn T. 2005. The cost of sustainability capital and the creation of sustainable value by companies. Journal of Industrial Ecology 9: 47-58.

Fried H., Lovell C.A.K. \& Schmidt S. (eds) 2007. The measurement of productive efficiency and productivity change. Oxford University Press, New York.

Greene W.H. 1980. Maximum likelihood estimation of econometric frontier functions. Journal of Econometrics 13: $26-57$.

Greene W.H. 2007. Econometric analysis. $6^{\text {th }}$ Edition, Pearson Education International, New Jersey.

Groeneboom P., Jongbloed G. \& Wellner J.A. 2001. A canonical process for estimation of convex functions: The "invelope" of integrated Brownian motion plus t(4). An- nals of Statistics 29: 1620-1652.

Hanson D.L. \& Pledger G. 1976. Consistency in concave regression. Annals of Statistics 4: 1038-1050.

Hildreth C. 1954. Point estimates of ordinates of concave functions. Journal of the American Statistical Association 49: 598-619.

Johnson A.L. \& Kuosmanen T. 2009. How operational conditions and practices effect productive performance? Efficient nonparametric one-stage estimators, paper presented at the European Workshop on Efficiency and Productivity Analysis (EWEPA), June 2326 2009, Pisa, Italy.

Jondrow J., Lovell C.A.K., Materov I.S. \& Schmidt P. 1982. On estimation of technical inefficiency in the stochastic frontier production function. Journal of Econometrics 19: 233-238.

Kortelainen M. \& Kuosmanen T. 2007. Eco-efficiency analysis of consumer durables using absolute shadow prices. Journal of Productivity Analysis 28: 57-69.

Kuosmanen T. 2006. Stochastic nonparametric envelopment of data: combining virtues of SFA and DEA in a unified framework. MTT Discussion Paper 3/2006.

Kuosmanen T. 2008. Representation theorem for convex nonparametric least squares. Econometrics Journal 11: 308-325.

Kuosmanen T. \& Fosgerau M. 2009. Neoclassical versus frontier production models? Testing for the presence of inefficiencies in the regression residuals. Scandinavian Journal of Economics 111: 317-333.

Kuosmanen T. \& Johnson A.L. 2009. Data envelopment analysis as nonparametric least squares regression. Operations Research: forthcoming.

Kuosmanen T. \& Kortelainen M. 2005. Measuring eco-efficiency of production with data envelopment analysis. Journal of Industrial Ecology 9: 59-72.

Kuosmanen T. \& Kortelainen M. 2007a. Valuing environmental factors in cost-benefit analysis using data envelopment analysis. Ecological Economics 62: 56-65.

Kuosmanen T. \& Kortelainen M. 2007b. Stochastic nonparametric envelopment of data: Cross-sectional frontier estimation subject to shape constraints. University of Joensuu, Economics DP No. 46.

Kuosmanen T. \& Kuosmanen N. 2009. How not to measure sustainable value (and how one might). Ecological Economics: forthcoming.

Meeusen W. \& van den Broeck J. 1977. Efficiency estimation from Cobb-Douglas production functions with composed error. International Economic Review 18: 435-445.

Meyer M.C. 1999: An extension of the mixed primal-dual bases algorithm to the case of more constraints than dimensions. Journal of Statistical Planning and Inference 81: 13-31.

Nevens F., Verbruggen I., Reheul D. \& Hofman G. 2006. Farm gate nitrogen surpluses and nitrogen use efficiency of specialized dairy farms in Flanders: Evolution and future goals. Agricultural Systems 88: 142-155.

Reinhard S., Lovell C.A.K. \& Thijssen G. 1999. Econometric estimation of technical and environmental efficiency: An application to Dutch dairy farms. American Journal of Agricultural Economics 81: 44-60.

Richmond J. 1974. Estimating the efficiency of production. International Economic Review 15: 515-521. 
Kuosmanen, T. \& Kuosmanen, N. Benchmark technology in sustainable value analysis

Timmer C.P. 1971. Using a probabilistic frontier production function to measure technical efficiency. Journal of Political Economy 79: 767-794.

Tyteca D. 1996. On the measurement of the environmental performance of firms - A literature review and a productive efficiency perspective. Journal of Environmental Management 46: 281-308.

Tyteca D. 1997. Linear programming models for the measurement of environmental performance of firms - Concepts and empirical analysis. Journal of Productivity Analysis 8: 183-197.

Tyteca D. 1998. Sustainability indicators at the firm level: Pollution and resource efficiency as a necessary condition toward sustainability. Journal of Industrial Ecology 2: $61-77$. van Passel S., Nevens F., Mathijs E., \& van Huylenbroeck G. 2007. Measuring farm sustainability and explaining differences in sustainable efficiency. Ecological Economics 62: 149-161.

Virtainen H. \& Nousiainen J. 2005. Nitrogen and phosphorus balances on Finnish dairy farms. Agricultural and Food Science 14: 166-180.

Winsten C.B. 1957. Discussion on Mr. Farrell's paper. Journal of the Royal Statistical Society Series A 120: 282-284.

Zaim O. 2004. Measuring environmental performance of state manufacturing through changes in pollution intensities: A DEA framework. Ecological Economics 48: 37-47.

\title{
SELOSTUS
}

\section{Vertailuteknologian merkitys tuotannon kestäryyden arvioinnissa Sovellutus suomalaisille maitotiloille}

\author{
Kuosmanen Timo ja Kuosmanen Natalia
}

Helsingin kauppakorkeakoulu ja MTT

Kestävä kehitys on monitahoinen käsite, johon sisältyy taloudellisen, ekologisen ja sosiaalisen kestävyyden ulottuvuudet. Yritystoiminnan kestävyyden mittaaminen on todettu tärkeäksi, mutta myös haastavaksi ongelmaksi. Yksi varteenotettavimmista kestävyyden mittaustavoista on Figgen ja Hahnin kehittämä sustainable value (SV) menetelmä. Artikkelin kirjoittajat ovat aikaisemmassa tutkimuksessaan kritisoineet alkuperäisen SV-estimaattorin rajoittavia lineaarisuusoletuksia. Nämä oletukset voidaan välttää kirjoittajien kehittämän yleistetyn SVmenetelmän avulla, joka mahdollistaa epälineaaristen vertailuteknologioitten käyttämisen ja niiden empiirisen estimoinnin.

Tutkimuksen tarkoituksena on arvioida vaihtoehtoisia parametrisia ja paramerittomia menetelmiä vertailuteknologian estimointiin yleistetyn SV-analyysin viitekehikossa. Kahdeksaa erilaista vertailuteknologian estimointiin yleisesti käytettyä menetelmää sovellettiin 332 suomalaisen maitotilan empiiriseen aineistoon. Kullakin menetelmällä saatujen tulosten perusteella lasket- tiin SV-indeksin arvot kullekin tilalle. Vaihtoehtoisia estimointimenetelmiä arvioitiin kriittisesti sekä ekonometrisen teorian että empiiristen tulosten valossa. Tulosten perusteella voidaan vetää seuraavat johtopäätökset:

1) Eri menetelmillä määritettyjen $S V$-indeksien korrelaatiot ovat korkeita ja positiivisia, joten eri menetelmillä arvioidut tilojen paremmuusjärjestykset kestävyyden suhteen ovat pitkälti yhdenmukaisia.

2) Parametrittomat menetelmät pystyvät joustavuutensa ansiosta selittämään suuremman osuuden (hehtaarikohtaisen) tuotoksen vaihtelusta tilojen välillä kuin vastaavat parametriset menetelmät.

3) Regressiomallien jäännöstermien jakaumat ovat vinoja. Keskimääräinen vertailuteknologia antaa siten tässä aineistossa harhaisen kuvan tilojen tuotantomahdollisuuksista.

4) Satunnaisvirheitten huomioon ottaminen kestävyyden määrittämisessä parantaa tulosten luotettavuutta. 